U norden

\title{
Tillsammans för jämställdhet - ett starkare Norden
}

Samarbetsprogram för det nordiska jämställdhetssamarbetet 2015-2018

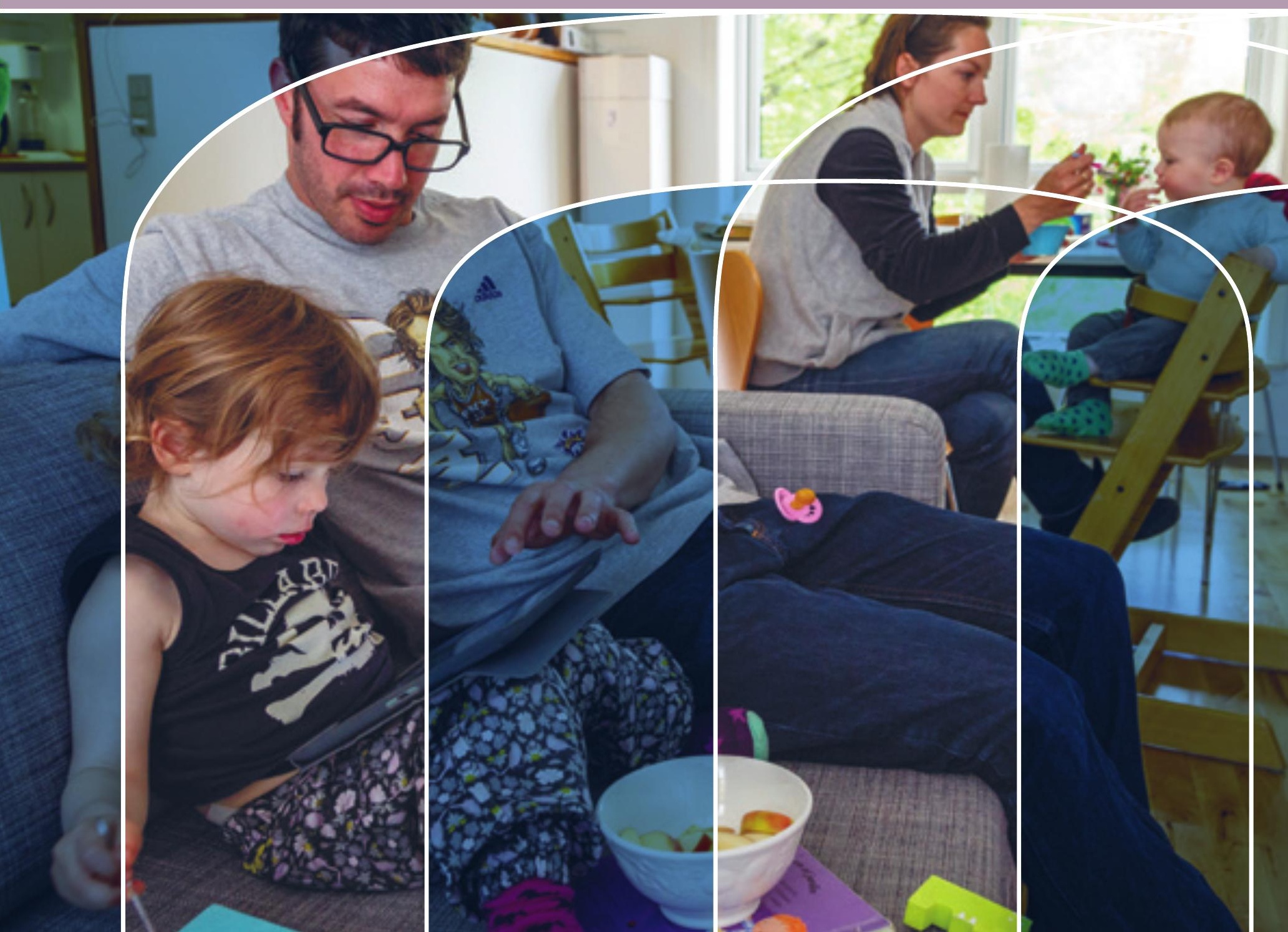


Tillsammans för jämställdhet - ett starkare Norden

Samarbetsprogram för det nordiska jämställdhetssamarbetet 2015-2018

ISBN 978-92-893-3819-6 (PRINT)

ISBN 978-92-893-3820-2 (PDF)

http://dx.doi.org/10.6027/ANP2014-757

ANP 2014:757

(C) Nordiska ministerrådet 2014

Layout: Erling Lynder

Foto: s. 6 Magnus Fröderberg; s. 1, 4, 6, 13, 16 Yadid Levy

Upplaga: 200

Typsnitt: Meta LF

Papper: Munken Polar

Tryck: Rosendahl Schultz Grafisk

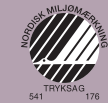

Printed in Denmark

www.norden.org/sv/publikationer

\section{Nordiska ministerrådet}

Ved Stranden 18

DK-1061 København K

Telefon (+45) 33960200

www.norden.org

\section{Det nordiska samarbetet}

Det nordiska samarbetet är ett av världens mest omfattande regionala samarbeten. Det omfattar Danmark, Finland, Island, Norge och Sverige samt Färöarna, Grönland och Åland.

Det nordiska samarbetet är politiskt, ekonomiskt och kulturellt förankrat och är en viktig partner i europeiskt och internationellt samarbete. Den nordiska gemenskapen arbetar för ett starkt Norden i ett starkt Europa.

Det nordiska samarbetet ska stärka nordiska och regionala intressen och värderingar i en global omvärld. Gemensamma värderingar länderna emellan bidrar till att stärka Nordens ställning som en av världens mest innovativa och konkurrenskraftiga regioner. 


\section{Tillsammans för jämställdhet - ett starkare Norden}

Samarbetsprogram för det nordiska jämställdhetssamarbetet 2015-2018

Det nordiska jämställdhetssamarbetet under programperioden 2015-2018

Organisering av arbetet

Det offentliga rummet

Välfärd och innovation

Milstolpar i det nordiska jämställdhetssamarbetet 1974-2014 



\section{Sammanfattning}

Målsättningen för det nordiska jämställdhetssamarbetet under programperioden 2015-2018 är att bidra till ett effektivt jämställdhetsarbete i de nordiska länderna, Färöarna, Grönland och Åland och att höja kunskapen om jämställdhet i Norden bland medborgare, parlamentariker och regeringar samt i Nordiska ministerrådets egna organ och projekt. Det nordiska samarbetet ska utgöra en samarbetsregion internationellt och bidra i internationella erfarenhetsutbyten t.ex. i FN. Samarbetet sker även i Nordens närområden: de baltiska staterna, nordvästra Ryssland och Arktis.

Samarbetsprogrammet 2015-2018 innehåller två övergripande teman: det offentliga rummet och välfärd och innovation. I programmet finns också två tvärgående teman: hållbar utveckling med fokus på mångfald och mäns och pojkars aktiva deltagande i jämställdhetsarbetet. Jämställdhetsintegrering är en strategi för genomförande av jämställdhetsprogrammet.

Inom ramen för temat det offentliga rummet strävar de nordiska länderna, Färöarna, Grönland och Åland efter att

- kvinnor och män har samma tillgång och möjlighet till inflytande, påverkningsmöjligheter och makt att delta i beslutsprocesser och i utformandet av välfärdssamhällena i Norden
- kvinnor och män i Norden har tillgång och tillträde till media på lika villkor

- sexualisering av det offentliga rummet motarbetas

- motverka motståndet till jämställdhet och motverka könsbaserade hatyttringar.

Inom ramen för temat välfärd och innovation strävar de nordiska länderna, Färöarna, Grönland och Åland efter att

- kvinnor och män, flickor och pojkar i Norden har samma möjligheter till utbildning, lärande och forskning samt utveckling av personliga ambitioner, intressen och talanger

- kvinnor och män i Norden har samma möjligheter att delta på arbetsmarknaden och till ekonomisk självständighet

- kvinnor och män i Norden har samma möjligheter att förena familje- och arbetsliv

- nolltolerans råder mot könsrelaterat våld

- öka kunskaperna om kvinnors och mäns, flickors och pojkars hälsa och att kvinnor och män, flickor och pojkar har samma tillgång till hälsovård och social service och möjligheter till hälsa och välmående. 

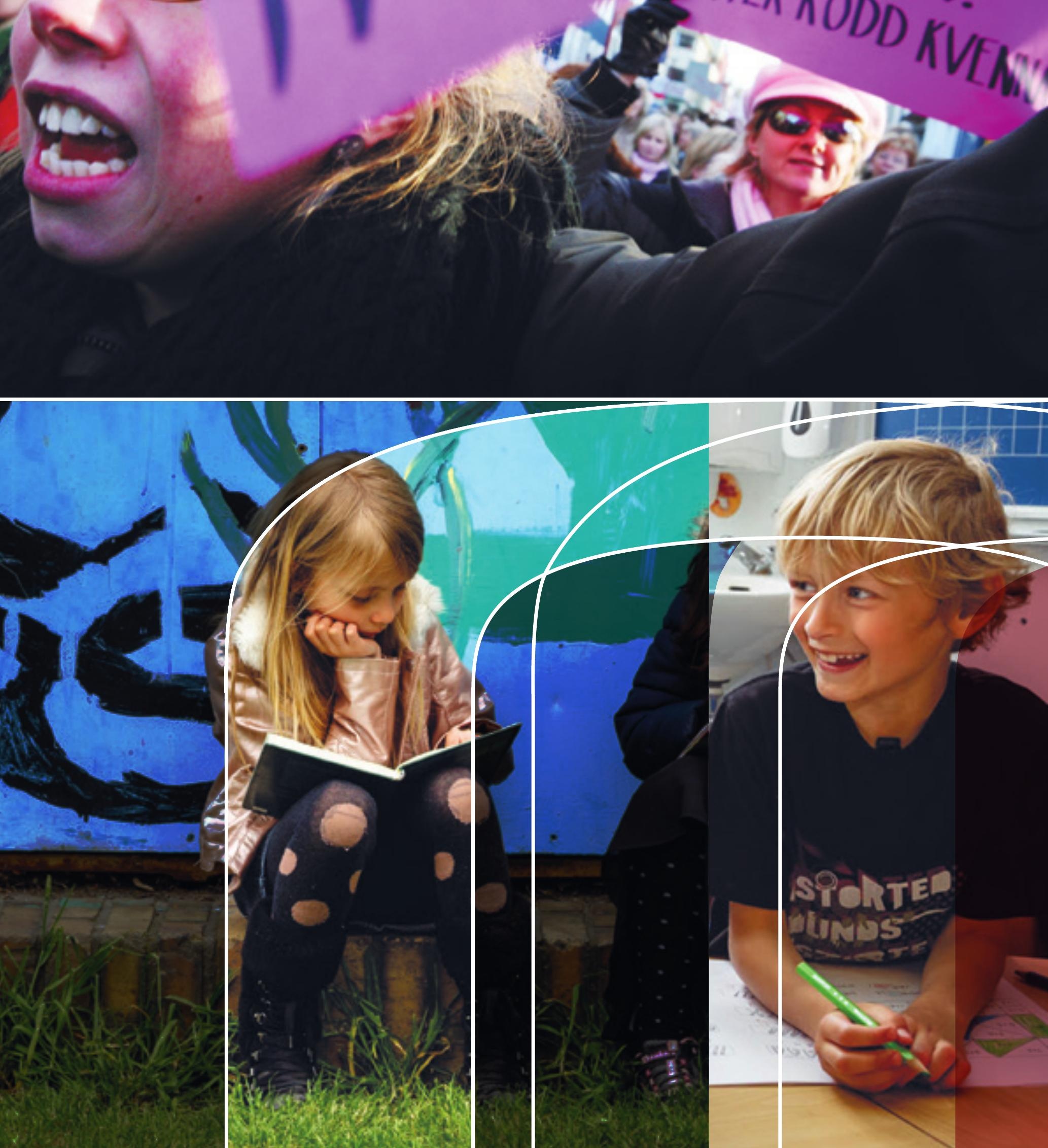


\section{Det nordiska jämställdhetssamarbetet under programperioden 2015-2018}

De nordiska ländernas, Färöarnas, Grönlands och Ålands samarbete kring jämställdhetsfrågor drivs av en gemensam nordisk vision om ett jämställt Norden med lika möjligheter, rättigheter och skyldigheter för alla invånare oberoende av kön.

Jämställdhet innebär att kvinnor och män, flickor och pojkar, har samma makt och inflytande och lika rättigheter, ansvar, skyldigheter och möjligheter på livets alla områden. I Norden har vi kommit långt $\mathrm{i}$ arbetet med jämställdhet $\mathrm{i}$ form av lagstiftning och politiska åtgärder men vi har inte uppnått reell jämställdhet mellan könen. För att uppnå ett jämställt samhälle krävs en övergripande jämställdhetspolitik som är till nytta inte bara för individen utan för hela samhället. Att ta tillvara både kvinnors och mäns kompetens, kunskap, erfarenhet och värderingar och möjlighet till påverkan berikar utvecklingen inom alla samhällsområden.

De nordiska länderna, Färöarna, Grönland och Åland har ibland valt olika vägar för att uppnå jämställdhet, byggt upp institutioner på olika sätt och valt olika åtgärder, men huvudsaken är att alla aktivt har arbetat för att uppnå goda resultat. Resultat uppstår inte av sig själva utan bakom ligger ett hårt arbete som man måste värna om för att inte råka ut för bakslag. Det är en fortlöpande process att bygga upp jämställda och demokratiska samhällen där kvinnor och män har samma möjligheter, rättigheter och ansvar. Jämställdhetsfrågor är inte en isolerad företeelse - jämställdhet berör allas våra liv.
Det nordiska jämställdhetssamarbetet har följande övergripande mål under programperioden 20152018:

1. Att bidra till ett effektivare och rikare nationellt jämställdhetsarbete i de nordiska länderna, Färöarna, Grönland och Åland.

2. Att stödja ländernas internationella förpliktelser på jämställdhetsområdet och skapa synergier på tvärs i Norden.

3. Att bidra till att höja kunskapen om jämställdhet och jämställdhetssamarbetet i Norden bland medborgare, parlamentariker och regeringar.

4. Att stödja alla sektorer i Nordiska ministerrådet $i$ arbetet med att främja jämställdhet.

1. Det nordiska jämställdhetssamarbetet ska bidra till ett effektivare och rikare nationellt jämställdhetsarbete i de nordiska länderna, Färöarna, Grönland och Åland.

Det nordiska jämställdhetssamarbetet har bidragit till ökad kunskap och fördjupad samverkan mellan länderna. Genom konferenser, möten, kunskapssammanställningar, rapporter och forskning får vi mer kunskap som för oss närmare målet om ett jämställt Norden. Det nordiska jämställdhetssamarbetet bidrar till vart och ett av de nordiska ländernas arbete med att uppnå jämställdhet och strävar efter att uppnå jämställdhet i Nordiska ministerrådets 
egna organ och projekt. Samarbetet syftar till att lära och stödja varandra genom att dela såväl goda som dåliga erfarenheter.

2. Det nordiska jämställdhetssamarbetet ska stödja ländernas samarbete $i$ internationella förpliktelser och skapa synergier på tvärs i Norden.

Jämställdhet är en stark profilfråga i Norden och det finns ett intresse $i$ andra länder av att få information om våra erfarenheter av arbetet med jämställdhet. Våra erfarenheter visar att jämställdhet inte endast är en rättvise- och demokratifråga utan också en ekonomisk nödvändighet och en grundpelare i de nordiska välfärdssamhällena. Norden ska fortsättningsvis vara en ansvarstagande samarbetsregion i ett internationellt perspektiv och genom dialog och diskussion medverka $\mathrm{i}$ internationella forum för att främja jämställdhet. Det nordiska samarbetets roll på jämställdhetsområdet är också att stödja ländernas samarbete $\mathrm{i}$ internationella förpliktelser och skapa synergier på tvärs i Norden.

Det nordiska jämställdhetssamarbetet vill utgöra en ansvarstagande samarbetsregion internationellt och samarbetar under programperioden därför med aktuella aktörer i den utsträckning som bedöms relevant.
Inom ramen för $\mathrm{FN}$ kommer det nordiska samarbetet att stödja de nordiska ländernas jämställdhetspolitiska initiativ och att synliggöra det nordiska jämställdhetssamarbetet.

Under programperioden kommer samarbete i Nordens närområden fortsättningsvis att prioriteras, speciellt i Baltikum, nordvästra Ryssland och Arktis. Det nordisk-baltiska samarbetet bygger på dialog och jämlikhet och baseras på ett separat nordisk-baltiskt samarbetsprogram och på Nordiska ministerrådets överordnade riktlinjer för samarbete med Estland, Lettland och Litauen. Samarbetet $\mathrm{i}$ nordvästra Ryssland siktar på att utveckla en god grannsämja mot bakgrund av en önskan om att stärka demokratin och jämställdheten $i$ hela regionen och baseras på Nordiska ministerrådets riktlinjer för samarbete med nordvästra Ryssland. Samarbetet i Arktis baseras på Nordiska ministerrådets samarbetsprogram för Arktis.

\section{Det nordiska jämställdhetssamarbetet ska bidra till att höja kunskapen om jämställd- het och jämställdhetssamarbetet i Norden bland medborgare, parlamentariker och regeringar.}

I Norden har vi genom åren utnyttjat gemensamma styrkepositioner för att skapa synergier och utbyta erfarenheter i syfte att utveckla effektiva lösningar 
på många olika områden, till gagn för medborgarna i de nordiska länderna, Färöarna, Grönland och Åland. Undersökningar visar att kunskapen om det nordiska samarbetet har sjunkit bland de nordiska medborgarna. Undersökningar visar också att jämställdhet uppfattas som en grundläggande värdering i de nordiska länderna, Färöarna, Grönland och Åland, samtidigt som det finns en minskande förståelse för betydelsen och nödvändigheten av ett aktivt jämställdhetsarbete. Genom att synliggöra det nordiska jämställdhetssamarbetet ska också kunskapen om jämställdhet och dess betydelse för de nordiska ländernas välfärdssamhällen tydliggöras. Jämställdhetssamarbetet i Norden ska skapa plattformar för diskussion på tvärs i Norden och de politiskt ansvariga bör aktivt delta i den opinionsskapande processen genom information och massmedia.

\section{Det nordiska jämställdhetssamarbetet ska stödja alla sektorer i Nordiska ministerrådet $i$ arbetet med att främja jämställdhet.}

De nordiska samarbetsministrarnas (MR-SAM) beslut om att integrera jämställdhet i Nordiska ministerrådets verksamhet utgör en metod för att skapa bättre förutsättningar för att kunna realisera Nordiska ministerrådets mål om jämställdhet mellan könen. Strategin innebär att alla sektorer ska integrera ett köns- och jämställdhetsperspektiv i sin verksamhet. Integreringen ska ske genom att samarbetsområdena använder redskap och rutiner som synliggör könsaspekterna av beslut och åtgärder. En förutsättning för jämställdhetsintegrering är att man utreder konsekvenserna av sina val och bedömningar ur ett jämställdhetsperspektiv och att man uppfyller de jämställdhetsmål sektorn beslutat om. Varje sektor har ansvar för att formulera och realisera konkreta och särskilda målsättningar för jämställdhet med utgångspunkt i varje samarbetsområdes särskilda problemställningar. Sektorerna rapporterar årligen om arbetet med jämställdhet. Rapporteringen sammanställs till Nordiska ministerrådets jämställdhetsredogörelse till Nordiska rådet som avges vid Nordiska rådets session.

Även om varje enskild sektor har ansvar för att främja jämställdheten inom sin verksamhet är det viktigt att jämställdhetsministrarna fortfarande har ansvar som initiativtagare och utvecklande expert för att fortsättningsvis föra en aktiv nordisk jämställdhetspolitik. En dialog och ett samarbete mellan de olika sektorerna och jämställdhetssektorn är en förutsättning för lyckad jämställdhetsintegrering, och jämställdhetssektorn har en stödjande och koordinerande roll $\mathrm{i}$ jämställdhetsintegreringsarbetet. 


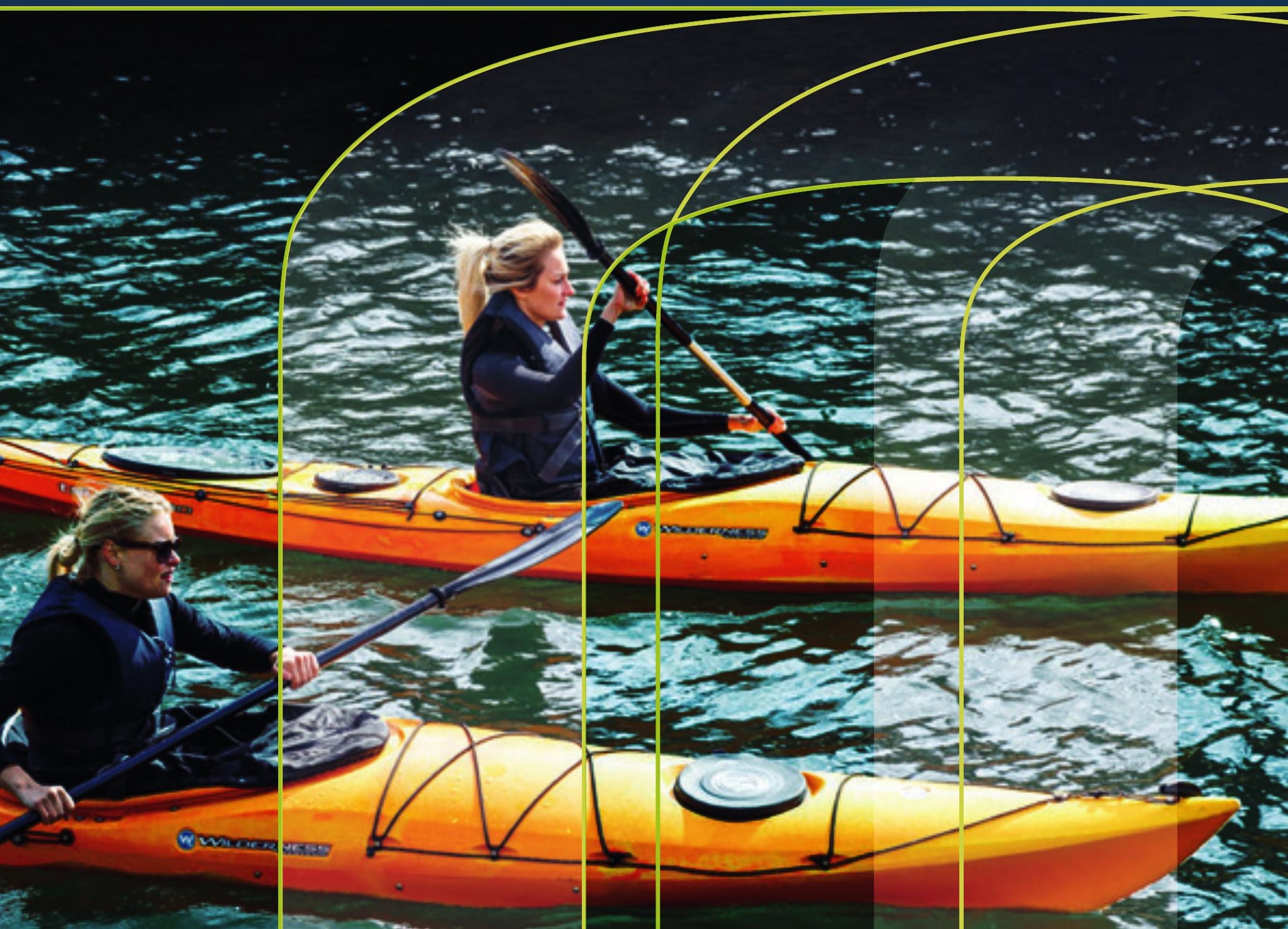




\section{Organisering av arbetet}

Ansvaret för det nordiska jämställdhetssamarbetet ligger hos ministerrådet för jämställdhet (MR-JÄM). Ämbetsmannakommittén för jämställdhet (ÄK-JÄM) ansvarar för att förbereda ärenden för MR-JÄM och verkställer dess beslut. Ordförandeskapet ansvarar för att leda samarbetet i MR- och ÄK-JÄM. Ministerrådets verksamhet presenteras i årliga sektorprogram där aktiviteterna för att uppnå målsättningarna i samarbetsprogrammet framställs. MR-JÄM har ett samarbetsorgan, NIKK (Nordisk information för kunskap om kön), med uppgift att förmedla och synliggöra forskning, politik och information på jämställdhetsområdet i ett nordiskt perspektiv. NIKK har också till uppgift att utlysa medel ur MRJÄM:s stödordning till projekt med ett nordiskt och jämställdhetspolitiskt mervärde.

Arbetet med jämställdhet ska underbyggas med välgrundade kunskaper och fakta såsom könsuppdelad statistik, genusforskning och kompetens om jämställdhet hos de som ansvarar för att arbeta aktivt med jämställdhetsfrågor. Arbetsmetoder kan vara opinionsbildning, förmedling av goda exempel, skapande av plattformar för tvärnordiska och internationella diskussioner, uppmuntran till forskning om jämställdhet på tvärnordisk nivå eller sammanställning av forskningsöversikter, koordinering av nätverk och utbyte av information om nationellt lagstiftningsarbete.

Samarbetet ska vara dynamiskt och fortlöpande anpassas till ländernas behov och de aktuella pro- blemställningar som de nordiska ländernas, Färöarnas, Grönlands och Ålands regeringar upptas av.

\section{Samarbetsprogrammets två övergripande teman}

Samarbetsprogrammet innehåller två övergripande teman: det offentliga rummet och välfärd och innovation. Inom dessa anges ett antal målsättningar som de nordiska jämställdhetsministrarna vill fokusera på under samarbetsperioden 2015-2018. De två breda och överordnade temana understryker och tydliggör behovet av målinriktat arbete för att främja jämställdhet. Jämställdhetsministrarna kommer även att under programperioden ha möjlighet att prioritera ytterligare frågor som kopplas till sektorprogrammen. Ett framgångsrikt jämställdhetsarbete är också beroende av tvärsektoriellt samarbete.

\section{Tvärgående teman: hållbar utveckling och mäns och pojkars aktiva deltagande}

I programmet ingår två tvärgående teman: hållbar utveckling med fokus på mångfald och mäns och pojkars aktiva deltagande i jämställdhetsarbetet.

Nordiska ministerrådets strategi för hållbar utveckling är ett styrdokument för alla sektorer i ministerrådet, och jämställdhetssektorn vill lyfta fram betydelsen av social hållbarhet och inom det ett mångfaldsperspektiv. Samhällets normer och värderingar kan lätt begränsa oss och leda till att olika kvaliteter, resurser och kompetens för personer med 
olika kön, ålder, tro, sexualitet, funktionsförmåga eller etnicitet inte tillvaratas. Jämställdhetssektorn arbetar därför genom strategin för hållbar utveckling med att integrera ett mångfaldsperspektiv i sin verksamhet i relevanta sammanhang.

Ett mans- och pojkperspektiv är centralt i jämställdhetsarbetet. Män och jämställdhet är ett område som har gått från att handla om mäns deltagande i kvinnors kamp för jämställdhet till att handla om mäns specifika jämställdhetsproblem t.ex. inom hälsa och välfärd, utbildning, marginalisering och faderskap/samhörighet. Kön är inte den enda förklaringen till skillnaderna mellan kvinnor och män, liksom skillnader inte nödvändigtvis är ett jämställdhetsproblem i sig, men det är centralt att undersöka och beakta mansrollen i olika situationer i samhället, på arbetsmarknaden och i familjen för att främja jämställdheten. En mer jämställd fördelning av omsorgsarbetet i familjer främjar både kvinnors möjligheter på arbetsmarknaden och mäns roll som fäder. Män i traditionellt kvinnodominerade yrken bryter mot den könsuppdelade arbetsmarknaden och främjar båda könens karriär- och arbetsmöjligheter och minskar det lönegap mellan kvinnor och män som uppstår på grund av könsuppdelningen. 


\section{Det offentliga rummet}

Kvinnors och mäns lika möjlighet att delta i formandet av politik och i utvecklingen av samhället är en grund för det demokratiska offentliga rummet. Både kvinnor och män, flickor och pojkar, har rätt att ta del av och bidra till diskursen i det offentliga rummet i media, politik, ekonomi och olika beslutsfattanden. I det offentliga rummet kan strukturer och stereotypa bilder av kvinnor och män, flickor och pojkar förstärkas vilket kan begränsa kvinnors och mäns lika möjlighet att delta i den demokratiska debatten. Det offentliga rummet omfattar olika typer och branscher av media såsom journalistik, reklam, datorspel och sociala medier.

De nordiska länderna, Färöarna, Grönland och Åland strävar efter att:

Kvinnor och män har samma tillgång och samma möjlighet till inflytande, påverkningsmöjligheter och makt att delta i beslutsprocesser och $i$ utformandet av välfärdssamhällena i Norden.

Norden är känt för sin förhållandevis höga andel kvinnor i parlamentariska församlingar och regeringar vilket är ett resultat av en över 100-årig process för att öka kvinnors representation både inom och utanför det politiska systemet i de enskilda länderna. Trots det fördelas fortfarande makt, ansvar och sociala resurser ojämnt mellan kvinnor och män i Norden. Kvinnor och män i de nordiska samhällena ska ha samma möjligheter att delta i beslutsprocesser i olika delar av samhället. Samhället behöver återspeglas i beslutsprocesserna för att stärka demokratin och dess funktionalitet. Förutfattade meningar, stereotypa uppfattningar och sociala normer får inte begränsa kvinnor och män från att ha samma möjligheter att forma och skapa politik, praktik och ekonomi.

\section{Kvinnor och män i Norden har tillgång och tillträde till media på lika villkor.}

Media spelar en central roll i att återspegla samhällets diversitet. Ett brett spektrum av forskning visar en skev representation mellan kvinnor och män i media och en skevhet i vem som förmedlar och gör nyheter i Norden. Dessutom är kvinnors andel i beslutsfattande befattningar i media lägre än männens, och kvinnor är underrepresenterade som experter och som föremål för nyheter.

\section{Sexualisering av det offentliga rummet motarbetas.}

Könsbaserade och stereotypa framställningar av kvinnor och män i det offentliga rummet motverkar målet om ett jämställt samhälle. Snäva medie- 
bilder av kvinnor och män, stränga krav på kropp, utseende och konkurrenskraftigt beteende samt tilltagande sexualisering av det offentliga rummet ger flickor och pojkar ett begränsat register av förebilder. Identiteten påverkas av hur kvinnor och män, flickor och pojkar framställs i massmedia, kultur och kommunikation. En central fråga är hur stereotyper om kön i samhället förmedlas och eventuellt förstärks genom media, inklusive sociala medier.

\section{Motståndet till jämställdhet och könsbaserade hatyttringar motverkas.}

Det existerar ett motstånd mot jämställdhet och feminism både globalt och i Norden. En diskussion om den strukturellt förankrade ojämställdheten mellan kvinnor och män, flickor och pojkar, huruvida den har utjämnats eller vem som gynnas pågår i viss grad $i$ Norden och är ofta grundad på fördomar. Motståndet mot jämställdhet tar sig uttryck bl.a. i anonyma hatyttringar som ofta är könsbaserade och ofta riktar sig mot kvinnor. En offentlig debatt som framhäver och upprepar negativa och stereotypa bilder och uppfattningar om bl.a. kvinnor bidrar till att förstärka motståndet. Genom att framhäva båda könens rättigheter, skyldigheter och möjligheter, diskutera jämställdhet och höja kunskapen om den strukturella ojämställdheten kan motståndet mötas. 


\section{aring $130=6$}

GIIUSL-

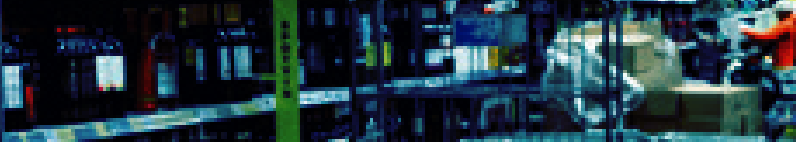

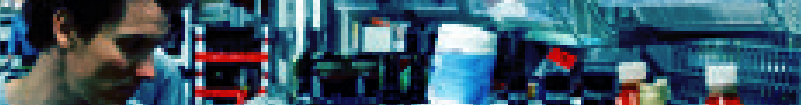

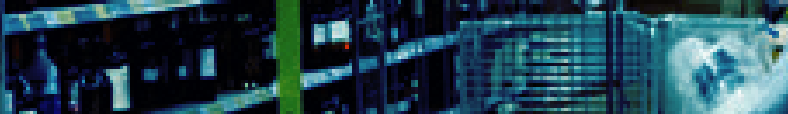
1 14 ti:

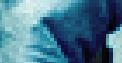
$\lim _{1}$

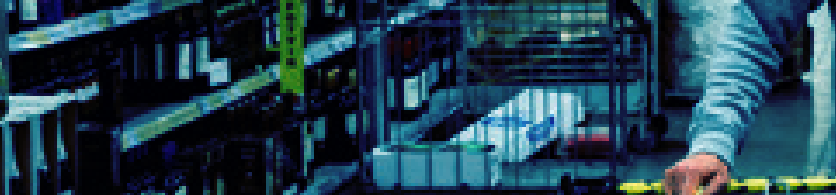

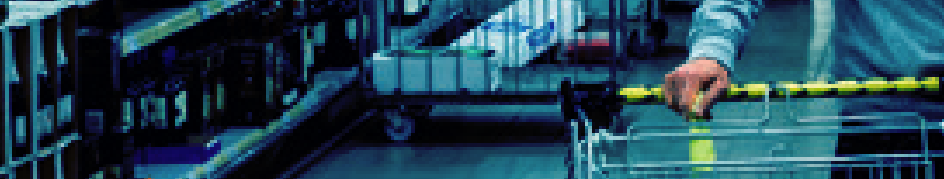
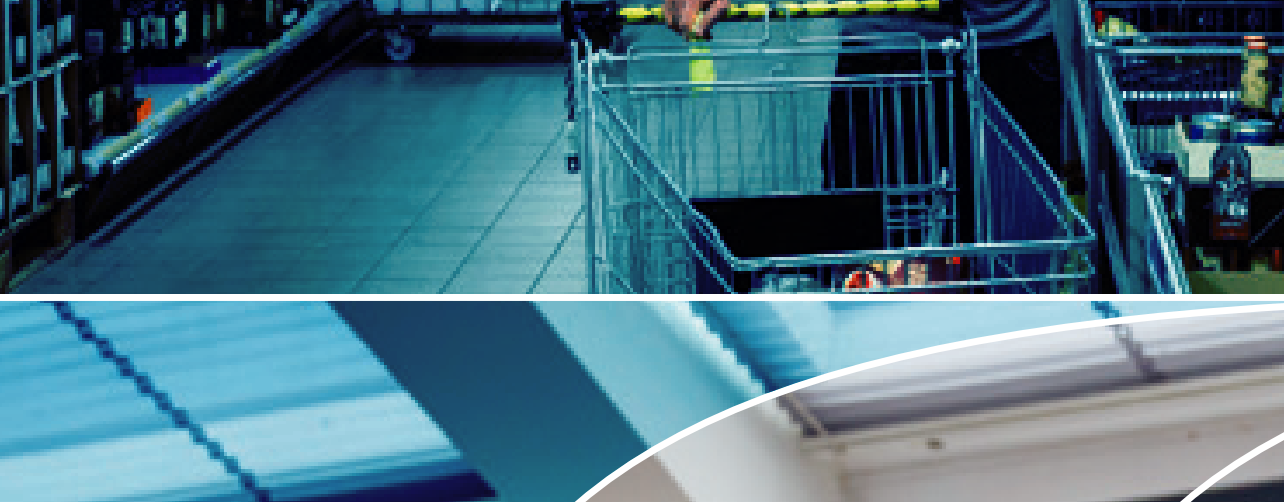

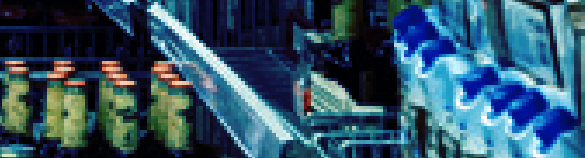

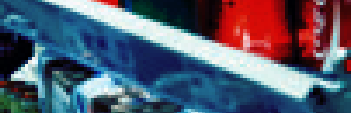

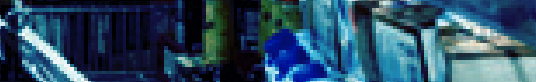

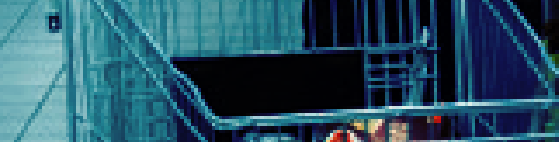
15. 3
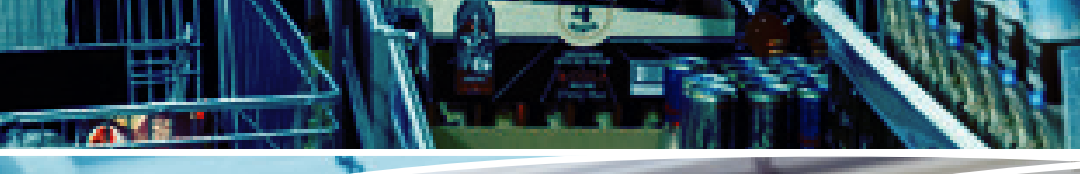

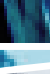

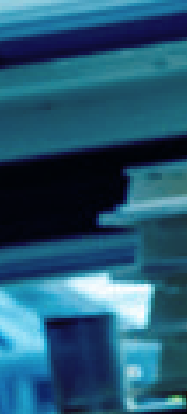

.
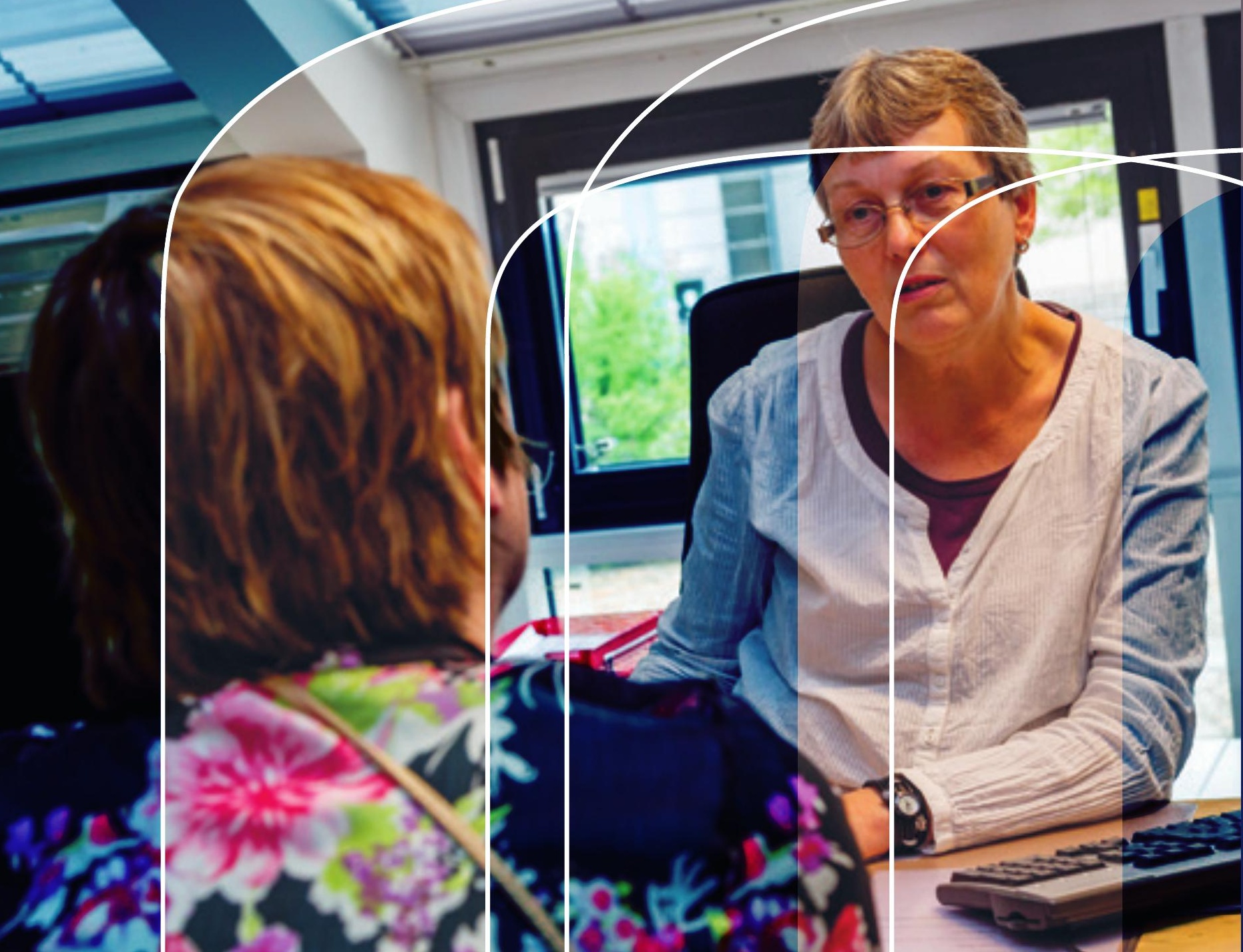


\section{Välfärd och innovation}

Norden är en innovativ region inom en rad olika områden såsom välfärd, utbildning, kreativitet, hållbarhet, entreprenörskap och forskning. De nordiska samhällena kännetecknas av att det drivs frågor om lika möjligheter för kvinnor och män att delta på arbetsmarknaden och i utbildning, att förena familje- och arbetsliv, tillgång till hälsotjänster och till kroppslig integritet. Jämställdhet är en grund för både innovation och välfärd. Innovativa sociala lösningar för att främja jämställdhet har stärkt utvecklingen av välfärdssamhällena i Norden.

De nordiska länderna, Färöarna, Grönland och Åland strävar efter att:

Kvinnor och män, flickor och pojkar i Norden har samma möjlighet till utbildning, lärande och forskning samt utveckling av personliga ambitioner, intressen och talanger.

I Norden idag är andelen kvinnor med högre utbildning större än andelen män. Flickor och pojkar ska ha samma tillgång till utbildning och valet av utbildning ska inte präglas av könsstereotyper. Barns könsroller formas tidigt och det är viktigt att läroplaner inkluderar ett jämställdhetsperspektiv. Det är nödvändigt att aktivt arbeta för att daghem och skola ger flickor och pojkar samma grundläggande kompetens och lika möjligheter, så att elever inte lämnar skolan med olika kunskaper och färdigheter beroende på kön. En annan viktig aspekt av jämställdhetsarbete i skolan är tillgång till studievägledning som inte grundar sig på traditionella könsbundna stereotyper och som lägger grunden till icke könsbundna utbildnings- och yrkesval. Samverkan med föräldrar, frivilligorganisationer inklusive ungdomsorganisationer, kommuner, regioner och den privata sektorn är centralt för att lyckas med jämställdhetsarbetet i skolan.

\section{Kvinnor och män i Norden har lika möjligheter att delta på arbetsmarknaden och till ekonomisk självständighet.}

Lika möjligheter till förvärvsarbete, inkomst och därmed ekonomisk självständighet är en grundläggande förutsättning för jämställdhet mellan kvinnor och män. Lika lön för lika arbete är en lagstadgad rättighet i alla de nordiska länderna och ett jämställdhetspolitiskt mål. En grundförutsättning för ekonomisk tillväxt är båda könens höga deltagande på arbetsmarknaden.

Ett av de jämställdhetspolitiska målen i de nordiska länderna har länge varit att skapa lika förutsättningar för kvinnor och män på arbetsmarknaden. Kvinnor och män ska ha lika möjligheter att välja yrke och nå högre befattningar. Den nordiska arbetsmarknaden kännetecknas också av att vara könssegregerad och kvinnor och män arbetar i olika 
branscher där de kvinnodominerade branscherna ofta är lågavlönade medan de mansdominerade branscherna ofta är högavlönade. Arbetsmarknaden kännetecknas också av en ojämn fördelning av kvinnor och män på olika befattningsnivåer vilket leder till att man inte utnyttjar de tillgängliga resurserna på bästa sätt.

\section{Kvinnor och män i Norden har samma möjligheter att förena familje- och arbetsliv.}

Kvinnor i Norden har idag i större grad än män ansvar för familj och hem, och det är i stora delar av Norden fortfarande svårare för män än för kvinnor att bli föräldra- eller vårdlediga. Man bör främja både kvinnors och mäns möjligheter att vara föräldrar, delta i barnuppfostran och bidra till familjens inkomst. Kvinnor i Norden idag jobbar också i högre grad än män deltid, ofta för att kunna kombinera arbete- och familjeliv vilket både har effekt på samhällsekonomin, den individuella löne- och karriärutvecklingen och storleken på pensionen. Att hitta en balans mellan arbets- och familjeliv är en utmaning för både kvinnor och män. En jämnare ansvars- och arbetsfördelning av såväl det betalda som obetalda arbetet eftersträvas också med tanke på lika möjligheter till fritidsaktiviteter och frivilligarbete.

\section{Nolltolerans mot könsrelaterat våld i Norden.}

Könsrelaterat våld $\mathrm{i}$ alla former påverkar mest kvinnor. Könsrelaterat våld innefattar till exempel våld i hemmet, våld i nära relationer, olika form av sexuellt våld, tvångäktenskap, kvinnlig könsstympning och hedersrelaterat våld och förtryck och människohandel för sexuella ändamål. Könsrelaterat våld är en kränkning av åtnjutande av mänskliga rättigheter och en form av diskriminering samt ett tecken på historiskt ojämlika maktrelationer mellan kvinnor och män. Könsrelaterat våld utgör ett hot mot offrets säkerhet, är ett hinder för jämställdhet och orsakar även stora ekonomiska utgifter för samhället. Riskgrupper för könsrelaterat våld måste skyddas och offrets rättigheter är centrala i arbetet mot könsrelaterat våld. Arbetet mot könsrelaterat våld kräver också preventiva åtgärder som innefattar förändringar i attityder och stereotypa könsroller. Arbetet bör involvera alla relevanta aktörer såsom myndigheter, privata sektorn, media och civilsamhället.

\section{Öka kunskaperna om kvinnors och mäns, flickors och pojkars hälsa och att kvinnor och män, pojkar och flickor har lika tillgång till hälsovård och social service och lika möjlig- heter till hälsa och välmående.}

Alla, oberoende av kön, har rätt till bästa möjliga fysiska, psykiska och sociala välbefinnande, hälsa och tillgång till hälsovård och social service för att ha möjlighet att delta på alla områden i det offentliga och privata livet. Idag finns olikheter mellan könen vad gäller tillgång till hälsovård och sociala tjänster, förväntad livslängd, tillgång till ändamålsenlig medicinsk undersökning och sjukskrivningar. Frågor som rör hälsa och välmående behöver beaktas ur ett jämställdhetsperspektiv för att säkra likvärdig hälsa för såväl kvinnor som män och flickor som pojkar. 


\section{Milstolpar i det nordiska jämställdhetssamarbetet 1974-2014}

\section{4}

Det nordiska jämställdhetssamarbetet fyller 40 år vilket markeras under årets lopp och en jubileumskonferens arrangeras i Reykjavik. MR-JÄM stöder Nordiskt Forum i Malmö 2014.

\section{Viktiga projekt:}

Tvärsektoriella projekt/sektorövergripande samarbeten

- Nordisk barnboksantologi

- Kön och medier - Nordiskt forum för ökad jämställdhet i medierna

- Kön och jämställdhet i Arktis

\section{Mäns/pojkars aktiva deltagande}

- Konferens om maskuliniteter i rörelse

- Jämställdhet på arbetsmarknaden

- Avslutningskonferens om deltid, kön och ekonomisk fördelning i Norden

- Konferens om lika lön

- Konferens om jämställdhet på arbetsmarknaden i Västnorden

\section{Nolltolerans mot könsrelaterat våld}

- Expertseminarium om nolltolerans mot könsrelaterat våld

- I samarbete med de baltiska länderna: International Conference on Sexual Assault

Vid FN:s kvinnokommissions (CSW) årliga möte arrangeras de nordiska sidoevenemangen: ministerpanelen Promoting gender equality through education och expertseminariet Do Everything: Break Stereotypes when Choosing Education and Work.

2013

Arbetet med jämställdhetsintegrering revitaliserades i Nordiska ministerrådet.

Viktiga projekt:

- Stöd för jämställdhetsintegrering internt $\mathrm{i}$ Nordiska ministerrådet

- Stöd för jämställdhetsintegrering i prioriteringsbudgeten

- Nordic Project on Gender Mainstreaming - best practice and effects

Klimat och hållbar utveckling

- Kön, klimatförändringar och biologisk mångfald - CSW och Washington

Tvärsektoriella projekt/sektorövergripande samarbeten

- Gender Balance in Research in the Nordic Countries

- Jämställdhet och unga vid kulturfestivalen Nordic Cool i Washington

Jämställdhet på arbetsmarknaden

- Studie och spridningskonferens om deltid, kön och ekonomisk fördelning i de nordiska länderna 
Jämställdhet inom utbildning

- Rapport och konferens om jämställdhet och jämställdhetsintegrering i förskolan och skolan i Norden

Kön, etnicitet och jämställdhet

- Konferens om jämställdhet i det moderna nordiska välfärdssamhället

Nolltolerans mot könsrelaterat våld

- Expertseminarium om riskbedömning vid parrelationsvåld i Norden

Vid $\mathrm{FN}$ :s kvinnokommissions (CSW) årliga möte arrangeras ministerpanelen From prevention to response - Engaging men and boys in preventing and ending violence against women and girls och expertseminariet Gender, Climate Change and Biodiversity i samarbete med MR-FJLS. Ett NGOsidoevenemang stöds: den nordiska modellen med kriscenter (skyddsboende).

\section{2}

MR-JÄM fortsätter arbetet med samarbetsprogrammet Jämställdhet skapar hållbara samhällen. Det nordiska nätverket om lika lön inleder sitt arbete.

Viktiga projekt:

Klimat och hållbar utveckling

- FN-konferensen Rio+20 - seminarium: Gender Equality is Sustainability

- Inspel till ny strategi för hållbar utveckling

Tvärsektoriella projekt/sektorövergripande samarbeten

- Gender Balance in Research in the Nordic Countries

- Trends and legal dilemmas - Nordic Conference on Anti-discrimination

- Seminarium om reproduktionsteknologi i Norden
Mäns/pojkars aktiva deltagande

- Arbetsgrupp för män och jämställdhet (fortsättning från 2011)

- Konferens om maskuliniteter i rörelse - män, jämställdhet och livskvalitet

- Samisk jämställdhetskonferens

- Motverka sexköp - en gemensam nordisk vägledning

- Seminarium om män och rekrytering till omsorgsyrken

Jämställdhet på arbetsmarknaden

- Trends and legal dilemmas - Nordic Conference on Anti-discrimination

- Nordiskt nätverk om lika lön i Norden

- Studie om deltid, kön och ekonomisk fördelning i de nordiska länderna

- Seminarium om män och rekrytering till omsorgsyrken

Vid FN:s kvinnokommissions (CSW) årliga möte arrangeras nordiska sidoevenemang med ministerpanelen Equality between Women and Men - the Nordic Way och expertseminariet Rural women - an economic potential.

Inom ramen för samarbetet med de baltiska länderna arrangeras ett nordisk-baltiskt rundabordssamtal om jämställdhet och media.

\section{1}

MR-JÄM fortsätter att fokusera på klimat och hållbar utveckling och en arbetsgrupp för män och jämställdhet arbetar under året.

Viktiga projekt:

- Jämställdhet och klimatförändringar, sidoevenemang vid hållbarhetskonferensen i Åbo 2011 
- Jämställdhet och klimatförändringar, sidoevenemang vid Nordiska rådets session 2011

- Equal Climate-portalen

- Arbetsgrupp för män och jämställdhet

- Engelsk översättning av Parental leave, childcare and gender equality in the Nordic countries (sv. Föräldraledighet, omsorgspolitik och jämställdhet i Norden)

- Konferensen Nordic Challenges, Future Possibilities - Gender Awareness in Schools and Teacher Education

Vid FN:s kvinnokommissions (CSW) årliga möte i New York arrangeras nordiska sidoevenemang med temat Beijing +15: Achievements and Challenges for Gender Equality - a Practical Approach och utställningen Gender and Climate Change visades.

\section{0}

Det nya fyraåriga samarbetsprogrammet för det nordiska jämställdhetssamarbetet 2011-2014 utarbetas under det danska ordförandeskapet.

Nordiska sidoevenemang om resultat och utmaningar när det gäller Beijing +15 vid $\mathrm{FN}$ :s kvinnokommissions (CSW) årliga möte i New York.

Utvärdering av Nordiska institutet för kunskap om kön (NIKK).

Viktiga konferenser/seminarier och projekt:

- Seminarium om jämställdhet i ett västnordiskt perspektiv, Ilulissat, Grönland

- Seminarium om framtida nordiskt jämställdhetssamarbete under Nordiska rådets session $\mathrm{i}$ Reykjavik, Island

- Projekt om finanskrisen och den könsuppdelade arbetsmarknaden
- Projekt om jämställdhet bland etniska minoriteter i Norden

- Projekt om globaliseringsinitiativ

Anmärkning: Dessutom har följande projekt som ligger utanför de prioriterade områdena genomförts/finansierats under programperioden: Kick-offseminarium för det nya samarbetsprogrammet (Norden).

\section{9}

Nordiskt sidoevenemang om jämställdhet och klimatförändringar vid FN:s kvinnokommissions (CSW) årliga möte i New York.

Nordiskt sidoevenemang om jämställdhet och klimatförändringar, COP-15 i Köpenhamn, Danmark.

Viktiga konferenser/seminarier och projekt:

- Seminarium om jämställdhet i lagen, Tórshavn, Färöarna.

- Seminarium om jämställdhet i skolan, Tórshavn, Färöarna.

- Nordisk konferens om jämställdhetsundervisning i skolan, Reykjavik, Island.

- Konferens om föräldraledighet, omsorgspolitik och jämställdhet mellan könen, Reykjavik, Island.

- Avslutningskonferens om kön och makt, Reykjavik, Island.

- Konferensen Gender Equality and Demography, Sankt Petersburg, Ryssland.

- Nordiskt projekt om jämställdhet och klimatförändringar.

- Nordiskt projekt om kön och kultur startas av Nordiska ministerrådet för utbildning och forskning. MR-JÄM stöder projektet. 
Rapporten Global press - nordiska lösningar? Nordisk globaliseringsbarometer 2008 utarbetas för det nordiska globaliseringsforumet i Sverige. Senare hålls en nordisk konferens om globalisering, jämställdhet och kön.

\section{8}

NB8-möte i Estland. Ett nytt samarbetsprogram för åren 2009-2010 godkänns.

De nordiska och baltiska jämställdhetsministrarna utarbetar ett nordisk-baltiskt Memorandum of Understanding för att bekämpa människohandel för sexuella ändamål.

Nordiskt sidoevenemang om bekämpning av mäns våld mot kvinnor vid $\mathrm{FN}$ :s kvinnokommissions (CSW) årliga möte i New York.

Utbildning i jämställdshetsintegrering/gender mainstreaming för ordförandena i ämbetsmannakommittéerna och anställda vid Nordiska ministerrådets sekretariat.

Viktiga konferenser/seminarier och projekt:

- Nordiskt seminarium om Men's violence against women, honour-related violence and oppression and measures to combat trafficking in human beings for sexual purposes. Nordiska rådets session.

- Nordisk-baltisk-rysk tvärsektoriell konferens om människohandel för sexuella ändamål, Sankt Petersburg, Ryssland.

\section{7}

Nordisk-baltiskt ministermöte. De nordiska jämställdhetsministrarna diskuterar människohandel för sexuella ändamål.
Nordiskt sidoevenemang om den nya nordiska papparollen vid FN:s kvinnokommissions (CSW) årliga möte i New York.

10th Anniversary of Women and Men in Dialogue, Riga, Lettland.

Avslutningskonferensen Män och jämställdhet, Oslo, Norge.

Nordisk-samisk jämställdhetskonferens, Oslo, Norge.

Konferensen Nordic-Baltic Police Women's Network, Tammerfors, Finland.

En ny rapport ges ut om hur att få barn inverkar på kvinnors och mäns löner. En konferens om temat arrangeras.

Viktiga konferenser/seminarier och projekt:

- Nordiskt projekt om ledarskap i Norden i ett genusperspektiv.

- Projekt om människohandel och prostitution i Norden.

- Den nordiska undersökningen Familje-og velferdspolitiske ordninger i Norden - ulike modeller och deres konsekvenser for likestilling mellom kjønnene presenteras.

\section{6}

MR-JÄM godkänner ett nytt samarbetsprogram för det nordiska jämställdhetsarbetet 2006-2010. Samarbetsprogrammet prioriterar två teman:

- Kön och makt

- Kön och ungdom 
Konferensen Kön, makt och samarbete/-verkan med och för ungdom.

Nordiskt sidoevenemang om Kvinnors delaktighet i politik och ledning vid $\mathrm{FN}$ :s kvinnokommissions (CSW) årliga möte i New York.

På Nordiska rådets session presenterar jämställdhetsministrarna resultaten av en kartläggning av hur de olika ministerråden arbetar med att integrera ett köns- och likställdhetsperspektiv i sitt arbete.

NB8 MR-möte, Tønsberg, Norge. De nordiska och baltiska jämställdhetsministrarna antar på mötet ett nordisk-baltiskt samarbetsprogram för jämställdhet för åren 2007-2008.

En nordisk vitbok om unga och jämställdhet presenteras för jämställdhetsministrarna av en nordisk ungdomspanel.

Viktiga konferenser/seminarier och projekt:

- Konferens om mansforskning, Reykjavik, Island.

- Konferensen Familje- och välfärdspolitiska ordningar i Norden.

- Konferensen The process towards integrating gender perspective in the budgetary process (gender budgeting) - the Nordic experience avslutar det nordiska projektet om hur man integrerar ett könsperspektiv i de nordiska statsbudgetarna.

- Seminarium om en samordnad insats för att bekämpa människohandel. Genomförs i samarbete med ÄK-S och ÄK-LAG.

- Seminariet Kjønn, kultur og kommunikation i det fremtidige nordiske samarbejde.

\section{5}

Nordiskt sidoevenemang Gender and Youth vid FN:S kvinnokommissions (CSW) årliga möte i New York.
En utvärdering av Nordiska institutet för kvinnooch könsforskning (NIKK) genomförs på uppdrag av ÄK-JÄM av Rambøll Management.

Viktiga konferenser/seminarier och projekt:

- Nordisk konferens om kön och unga med speciellt fokus på pojkars och flickors utbildnings- och yrkesval.

- Konferens om hur pornografins utbredning inverkar på flickornas och pojkarnas uppfattning om kön.

- Seminarium om män och jämställdhet, Köpenhamn, Danmark.

- Seminarium om män mellan arbetslivet och familjen, Finland.

- Projektet Samarbeta jämt i Norden följer upp tidigare seminarium om integration och jämställdhet.

\section{4}

Jubileumsseminarium - 30 år av nordiskt jämställdhetssamarbete, Reykjavik, Island.

Handlingsplan för män och jämställdhet 2004-2005 godkänns. Handlingsplanen tar upp fyra teman: könssocialisering, män och våld, män och den könsuppdelade arbetsmarknaden samt män mellan arbetsliv och familj. En rad aktiviteter startas.

NB8-ministermötet antar ett nytt nordisk-baltiskt samarbetsprogram 2004-2006. Ministrarna beslutar att föreslå en samordning av myndigheternas, organisationernas och de olika arbetsgruppernas insatser i kampen mot människohandel.

Ett samarbete inleds med ministerrådet för narkotika och ministerrådet för social- och hälsopolitik med speciellt fokus på nordvästra Ryssland. Det utarbetas en Actionplan on Social Well Being som presenteras på ett kick-off-seminarium i Sankt Petersburg i september. 
Nordiskt sidoevenemang vid ministermötet Northern Dimension Partnership on Public Health and Social Wellbeing (NDPHS) i Tallinn, Estland.

Viktiga konferenser/seminarier och projekt:

- Konferensen Gender, Environment and Social Development in the West Nordic Countries and Arctic Areas, Akureyri, Island.

- 10th Anniversary Seminarium Nordic Forum, Åbo, Finland. Seminariet samlar deltagare från de nordiska och baltiska länderna såväl som från nordvästra Ryssland och Polen.

- Det nordiska forskningsprogrammet om den nordiska mannen påbörjas.

- Projektet Integrering av ett könsperspektiv i de nordiska statsbudgetarna startar. Projektet är ett samarbetsprojekt mellan ÄK-FINANS och ÄK-JÄM.

- Projektet $P a ̊$ sporet av likelön startar som del av ett samarbete mellan ÄK-JÄM och ÄK-A.

\section{3}

Viktiga konferenser/seminarier och projekt:

- Konferensen Integration och jämställdhet, Malmö, Sverige

- 3rd Baltic Sea Women's Conference on Women and Democracy, Tallinn, Estland

- Nordiskt projekt om pornofiering av det offentliga rummet

\section{2}

Nordisk-baltisk kampanj mot handel med kvinnor genomförs i de nordiska och baltiska länderna. Kampanjen är ett samarbete mellan ländernas justitie- och jämställdhetsministerier.

Möte om jämställdhet mellan kvinnor och män i ett flerkulturellt Norden, Oslo, Norge.

Ny hemsida lanseras: gender.norden.org
Viktiga konferenser/seminarier och projekt:

- Nordisk forskningskonferens Subjekt, politik och könskonstruktion: det jämställda Norden som framtidsverkstad, Stockholm, Sverige.

- Klart vi har likestilling - er de noe å mase om? Nordisk konferens om flickors och pojkars könssocialisering i det offentliga rummet.

\section{1}

Women and Democracy - The Second Conference Reykjavik-Vilnius, Vilnius, Litauen. I samband med konferensen arrangeras ett nordisk-baltiskt möte mellan jämställdhetsministrarna. På mötet godkänner ministrarna ett nordisk-baltiskt samarbetsprogram för 2001-2003.

Viktiga konferenser/seminarier och projekt:

- Taking Wing - konferens om Gender Equality and Women in the Arctic, Saariselkä, Finland.

- Towards Gender Responsive Budgeting - högnivåkonferens, Bryssel, Belgien.

- Kan mænd? kommer ut, och konferensen Mænd, arbejdsliv og ligestilling arrangeras i Köpenhamn, Danmark.

\section{0}

MR-JÄM godkänner ett nytt samarbetsprogram för det nordiska jämställdhetsarbetet 2001-2005.

Samarbetsprogrammet prioriterar tre teman:

- Integrering av ett genusperspektiv i de nordiska statsbudgetarna

- Män och jämställdhet

- Våld mot kvinnor

Viktiga konferenser/seminarier och projekt:

- Gender Equality and the Future - 2nd Baltic Sea Women's Conference, Helsingfors, Finland.

- Konferensen Gender Mainstreaming Competiveness \& Growth, Paris, Frankrike. 
- Gender Mainstreaming i Norden - en strategi för jämställdhet, arbetsmarknads- och ungdomspolitik, slutrapporten från det nordiska mainstreamingprojektet ges ut.

\section{9}

Under konferensen Women's World som arrangeras i Tromsø, Norge, hålls ett nordiskt ministerrådsmöte och de nordiska jämställdhetsministrarna deltar i en debatt om välfärd i Norden.

Viktiga konferenser/seminarier och projekt:

- Konferensen Women and Democracy at the Dawn of the New Millenium, Reykjavik, Island,

- Likestillte demokratier? Kjønn og politikk i Norden kommer ut.

\section{7}

Handlingsplan för män och jämställdhet godkänns av MR-JÄM.

På initiativ av MR-JÄM och MR-SAM godkänns en plan om integrering av jämställdhet i verksamheten vid NMR:s sekretariat.

Det första nordisk-baltiska jämställdhetsministermötet arrangeras. Ett samarbetsprogram för det nordisk-baltiska samarbetet för 1998-2000 godkänns.

Viktiga konferenser/seminarier och projekt:

- Nordisk konferens Kvinnor, arbete och ekonomi, Reykjavik, Island

- Nordisk-baltisk konferens Women and Men in Dialogue, Valmiera, Lettland

\section{6}

Viktiga konferenser/seminarier och projekt:

- Nordiskt projekt om Gender Mainstreaming.

- Norden och närområdena - kartläggning av jämställdhetssamarbete kommer ut.

\section{5}

MR-JÄM godkänner ett nytt samarbetsprogram för det nordiska jämställdhetsarbetet 1995-2000.

Samarbetsprogrammet prioriterar fem teman:

- Att främja kvinnors och mäns lika tillgång till de politiska och ekonomiska beslutsprocesserna

- Att främja kvinnors och mäns ekonomiska jämställdhet och inflytande

- Att främja ett jämställt arbetsliv

- Att förbättra både kvinnors och mäns möjligheter att förena föräldraskap och förvärvsarbete

- Att påverka den europeiska och den internationella utvecklingen på jämställdhetsområdet

Nordiska institutet för kvinno- och könsforskning (NIKK) grundas och placeras vid Universitetet i Oslo.

\section{4}

Nordiskt Forum, Åbo, Finland. I samband med forumet hålls ett ministerrådsmöte mellan de nordiska jämställdhetsministrarna.

Women and Men in the Nordic countries, Facts and Figures 1994 ges ut.

Publikationen Från kvinnolön till likalön - från kunskap till handling ges ut.

\section{3}

Publikationen Kvinnelønnas mysterier - myter og fakta om lønnsdannelsen ges ut.

\section{0}

Nordiskt projekt om lika lön för män och kvinnor i Norden. Løn efter fortjeneste - rapport från Nordiska ministerrådets projekt Ligeløn for kvinder og mænd $i$ Norden som ger en översikt över och diskuterar arbetsbedömning som ett hjälpmedel i arbetet för lika lön i Norden och internationellt. 


\section{9}

Vi har väntat länge nog - handbok i kvinnorepresentation ges ut på danska, finska, isländska, norska och svenska.

\section{8}

Nordiskt Forum Oslo, Norge. På forumet arrangeras en officiell nordisk jämställdhetskonferens.

\section{7}

MR-JÄM godkänner ett nytt samarbetsprogram för det nordiska jämställdhetsarbetet 1989-1993. Samarbetsprogrammet prioriterar två teman:

- Kvinnors roll i den ekonomiska utvecklingen

- Kvinnors och mäns möjligheter att kombinera familjeliv och arbetsliv

Viktiga konferenser/seminarier och projekt:

- Nordiskt projekt om män och jämställdhet

- Nordiskt projekt om muslimska invandrarkvinnor

- Nordiskt projekt om fler kvinnor i IT-branschen

- Nordiskt projekt Kan vi bo tillsammans?

Statistisk rapport om kvinnor och män i Norden ges ut.

\section{6}

Det nordiska BRYT-projektet startar. Syftet är att bryta upp den könsuppdelade arbetsmarknaden.

Det todelte arbejdsmarked - nordisk rapport ges ut.

\section{5}

Boken Blomster \& Spark, Samtaler med kvindelige politikere i Norden ges ut av Nordiska ministerrådet.

\section{2}

Det första samarbetsprogrammet för det nordiska jämställdhetsarbetet godkänns av ministerrådet för jämställdhet.
Viktiga konferenser/seminarier och projekt:

- Nordiskt projekt om kvinnor i nordisk politik

- Nordiskt projekt om våld i parförhållanden

\section{1}

En rådgivare som arbetar med jämställdhet som sitt huvudsakliga arbetsområde anställs vid Nordiska ministerrådets sekretariat.

Möte mellan de centrala nordiska arbetsgivarorganisationerna och ministerrådet för jämställdhet.

Nordiskt projekt om den tekniska utvecklingens betydelse för kvinnors och mäns jämställdhet $\mathrm{i}$ arbetslivet.

\section{0}

Jämställdhetsministrarna övertar ansvaret för det nordiska jämställdhetssamarbetet. Det hålls ett möte mellan jämställdhetsministrarna och Nordiska rådets social- och miljöutskott.

Möte mellan jämställdhetsutskottet och Nordens Fackliga samorganisation, Oslo, Norge.

Nordiskt projekt om tudelade arbetsmarknader i Norden.

\section{9}

Kontaktmöte om nordiskt jämställdhetssamarbete arrangeras mellan representanter för Nordiska ministerrådet, Nordiska rådet, Nordens Fackliga samorganisation, nordiska arbetsgivarorganisationer, representanter för nationella kvinnoorganisationer och tjänstemän från en rad ministerier i de nordiska länderna.

Nordiskt projekt om samhällsplanering och boendeformer. 


\section{8}

På ett möte mellan Nordiska rådets social- och miljöutskott och samarbetsministrarna för Nordiska ministerrådet godkänns handlingsplanen för nordiskt samarbete om jämställdhetsfrågor. På mötet föreslås det att man upprättar en ämbetsmannakommitté för jämställdhetsfrågor (ÄK-JÄM).

Nordisk jämställdhetsbulletin nr 1 kommer ut i juni 1978.

Nordiskt projekt om äktenskap och försörjning i Norden.

\section{7}

Nordiska rådets social- och miljöutskott föreslår att en handlingsplan för nordiskt samarbete i jämställdhetsfrågor ska presenteras på Nordiska rådets session följande år.

Viktiga konferenser/seminarier och projekt:
- Nordiskt seminarium Retsbeskyttelse af ligestilling mellem kvinder og mænd i Norden, Esbo, Finland

- Nordiskt projekt om massmedier och jämställdhet

- Nordiskt projekt om föräldraledighet

\section{6}

Nordiskt seminarium om jämställdhet i familje- och arbetslivet, Glumslöv, Sverige.

\section{5}

En nordisk kontaktgrupp för jämställdhetsfrågor tillsätts och det första kontaktgruppsmötet hålls i april 1975.

\section{4}

Nordiska ministerrådet beslutar i december 1974 att alla nordiska regeringar ska utse en person som ska hålla kontakt med de övriga nordiska regeringarnas administrationer i jämställdhetsfrågor. 


\section{norden}

Nordiska ministerrådet

Ved Stranden 18

DK-1061 København K

www.norden.org

Tillsammans för jämställdhet

- ett starkare Norden

Målsättningen för det nordiska jämställdhetssamarbetet under programperioden 2015-2018 är att bidra till ett effektivt jämställdhetsarbete i de nordiska länderna, Färöarna, Grönland och Åland och att höja kunskapen om jämställdhet i Norden bland medborgare, parlamentariker och regeringar samt i Nordiska ministerrådets egna organ och projekt. Det nordiska samarbetet ska utgöra en samarbetsregion internationellt och bidra i internationella erfarenhetsutbyten t.ex. i FN. Samarbetet sker även i Nordens närområden: de baltiska staterna, nordvästra Ryssland och Arktis. 